\title{
3-D analytical method for the discontinuous behaviour of large dams against surface earthquake faults
}

\author{
Y. Ariga \\ Graduate School of Science and Technology, Hirosaki University, Japan
}

\begin{abstract}
Confirmation and the securing of safety against a surface earthquake fault is an important subject for long and large structures, such as dams, tunnels, railways, highways, and so forth. About 100 years ago, several dams constructed along the San Andreas Fault were damaged by surface fault displacement during the 1906 San Francisco Earthquake. Recently, the Shih-Kang Dam was destroyed by surface fault displacement during the 1999 Taiwan Chi-chi Earthquake. As for the seismic safety evaluation against strong earthquake motions, many analytical methods have been practically developed thus far. However, the analytical method for evaluating safety against fault displacement has not yet been established. We have devised an analytical method for evaluating the discontinuous behaviour of concrete dams by applying the 3-D dynamic analysis method for the coupled dam-joint-foundation-reservoir system. The applicability of the method proposed in this study was examined by the analyses for the concrete gravity dam.
\end{abstract}

Keywords: fault displacement, 3-D dynamic analysis, discontinuous behaviour, concrete dam, seismic safety.

\section{Introduction}

The Upper Crystal Dam (earth-fill, height 23m), the Upper Howell Dam (earthfill, height $11 \mathrm{~m}$ ), the Old San Andreas Dam (earth-fill, height 8.5m) and so forth, which were constructed along the San Andreas Fault, were damaged by fault displacement during the 1906 San Francisco Earthquake [1, 2]. The Shih-Kang Dam (concrete gravity, height $25 \mathrm{~m}$ ) was destroyed by the vertical relative 
displacement of about 7.5m during the 1999 Taiwan Chi-chi Earthquake [3]. The existing dams damaged by the surface fault displacement are summarized in table 1. Taking these historical cases into consideration, we have studied and devised an analytical method for evaluating safety against fault displacement.

Table 1: $\quad$ Existing dams damaged by surface fault displacement.

\begin{tabular}{|l|l|l|l|}
\hline Dam Name & $\begin{array}{c}\text { Country } \\
\text { Completion }\end{array}$ & $\begin{array}{c}\text { Dam Type } \\
\text { Height }\end{array}$ & $\begin{array}{c}\text { Earthquake/Fault } \\
\text { Displacement measured }\end{array}$ \\
\hline $\begin{array}{c}\text { Upper } \\
\text { Crystal } \\
\text { Springs }\end{array}$ & $\begin{array}{l}\text { USA } \\
\text { California } \\
1878\end{array}$ & $\begin{array}{l}\text { Earth-fill } \\
\text { H:23m }\end{array}$ & $\begin{array}{l}\text { 1906 San Francisco Earthquake } \\
\text { San Andreas Fault } \\
\text { Vertical relative disp. } \fallingdotseq 2.4 \mathrm{~m}\end{array}$ \\
\hline $\begin{array}{l}\text { Lower } \\
\text { Howell }\end{array}$ & $\begin{array}{l}\text { USA } \\
\text { California } \\
1877\end{array}$ & $\begin{array}{l}\text { Earth-fill } \\
\text { H:12m }\end{array}$ & $\begin{array}{l}\text { 1906 San Francisco Earthquake } \\
\text { San Andreas Fault } \\
\text { Break of drain pipe of } \phi 25 \mathrm{~cm}\end{array}$ \\
\hline $\begin{array}{l}\text { Upper } \\
\text { Howell }\end{array}$ & $\begin{array}{l}\text { USA } \\
\text { California }\end{array}$ & $\begin{array}{l}\text { Earth-fill } \\
\text { H:11m }\end{array}$ & $\begin{array}{l}\text { 1906 San Francisco Earthquake } \\
\text { San Andreas Fault } \\
\text { Cracks }\end{array}$ \\
\hline $\begin{array}{c}\text { Old } \\
\text { San } \\
\text { Andreas }\end{array}$ & $\begin{array}{l}\text { USA } \\
\text { California }\end{array}$ & $\begin{array}{l}\text { Earth-fill } \\
\text { H:8.5m }\end{array}$ & $\begin{array}{l}\text { 1906 San Francisco Earthquake } \\
\text { San Andreas Fault } \\
\text { Horizontal relative disp. } \fallingdotseq 2.1 \mathrm{~m}\end{array}$ \\
\hline Shih-kang & $\begin{array}{l}\text { Taiwan } \\
\text { (China Taipei) }\end{array}$ & Concrete \\
gravity & $\begin{array}{l}\text { 1999 Taiwan Chi-chi Earthquake } \\
\text { Vertical relative disp. } \fallingdotseq 7.5 \mathrm{~m} \\
\text { Dam break }\end{array}$ \\
\hline
\end{tabular}
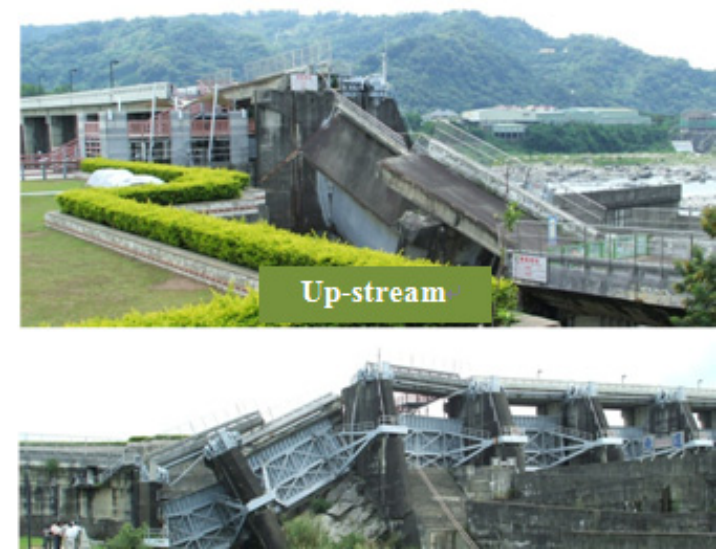

Figure 1: The Shih-Kang Dam damaged by vertical relative displacement during the 1999 Taiwan Chi-chi Earthquake. 


\section{Analytical method for evaluating the discontinuous behaviour of concrete dams against surface fault displacement}

\subsection{Necessity of study}

After the 1999 Taiwan Chi-chi Earthquake, studies on the analytical method with regard to surface earthquake faults were made. Analytical methods, such as the applied element method [4], the non-linear stochastic finite element method [5], the Lagrangian particle finite difference method [6], and so forth, have been reported for evaluating the deformation of ground and earthquake behaviour of structures. However, the analytical method with regard to dams has not yet developed. Taking this background into consideration, we have studied the analytical method to evaluate the interaction between dams and surface earthquake faults.

\subsection{Analytical method proposed}

\subsubsection{Analytical model for dam-joint-foundation-fault system}

The 3-D dynamic analysis method for the coupled dam-joint-foundationreservoir system [7] is applied for evaluating the interaction between the dam and the surface earthquake fault, by supposing the phenomenon as appeared in the 1999 Taiwan Chi-chi Earthquake at the Shih-Kang Dam. In this study, the boundary condition of the analytical model and the way to input an acceleration wave are contrived.

The 3-D dynamic analysis model for a coupled dam-foundation-fault system, which is made by assuming that the surface earthquake fault exists just below the dam, is shown in fig. 2 (general model). The width and the depth of the general model are $1335 \mathrm{~m}$ and $1094 \mathrm{~m}$, respectively.

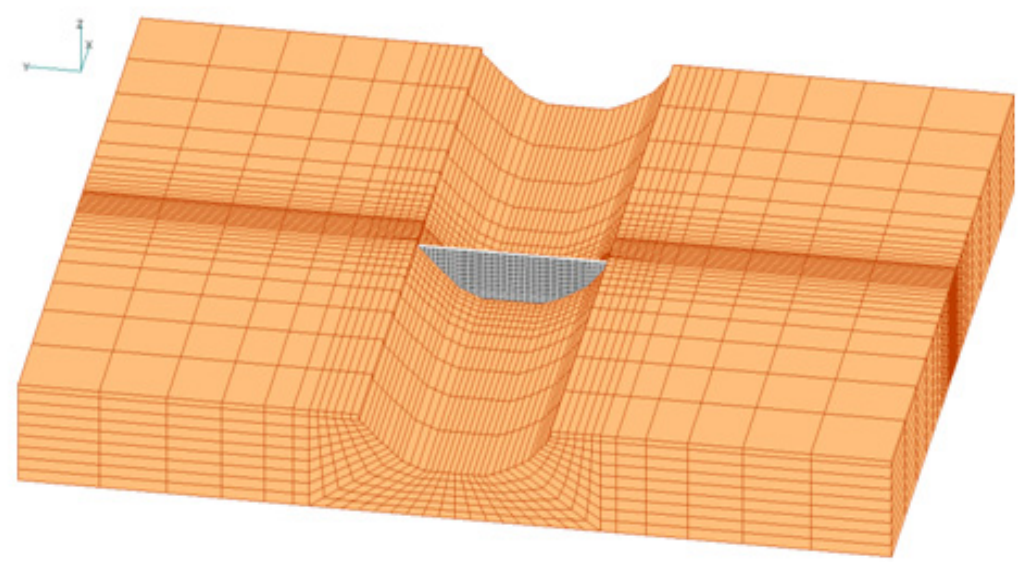

Width: $1335 \mathrm{~m}$, Depth: $1094.4 \mathrm{~m}$, Height: $162 \mathrm{~m}$

Figure 2: $\quad$ Analytical model (general model). 
Fig.3 shows the partial model, which was enlarged in order to indicate the analytical results. The width and the depth of the partial model are $445 \mathrm{~m}$ and $218.88 \mathrm{~m}$. This analytical model was identified by the $3-\mathrm{D}$ simulation analysis for the actual earthquake behaviour of the existing concrete dam by utilizing the earthquake motions recorded in the 1993 Kushiro-oki Earthquake (M7.8, Epicentral distance $108 \mathrm{~km}$ ) [8].

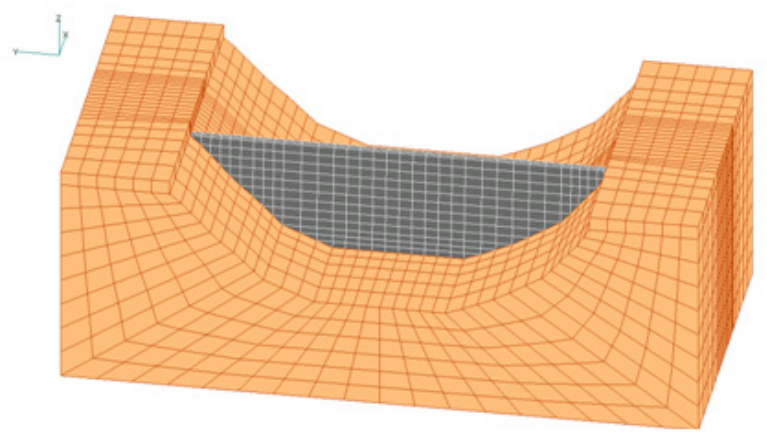

Width: $445 \mathrm{~m}$, Depth: $218.88 \mathrm{~m}$, Height: $162 \mathrm{~m}$

Figure 3: $\quad$ Partial model around the dam.

Table 2: $\quad$ Dynamic property values of the dam and the foundation.

\begin{tabular}{|l|c|c|l|l|}
\hline Items & $\begin{array}{l}\text { Shear } \\
\text { modulus } \\
\mathrm{N} / \mathrm{mm}^{2}\end{array}$ & $\begin{array}{l}\text { Density } \\
\mathrm{t} / \mathrm{m}^{3}\end{array}$ & $\begin{array}{l}\text { Poisson's } \\
\text { ratio }\end{array}$ & $\begin{array}{l}\text { Damping } \\
\text { Factor }\end{array}$ \\
\hline $\begin{array}{l}\text { Rock } \\
\text { foundation }\end{array}$ & 9380 & 2.6 & 0.3 & $5.0 \%$ \\
\hline $\begin{array}{l}\text { Dam } \\
\text { concrete }\end{array}$ & 11032 & 2.4 & 0.2 & $5.0 \%$ \\
\hline
\end{tabular}

\subsubsection{Model of the fault and the joints}

The distribution of the fault just below the dam, the contraction joints within the dam body, and the peripheral joint along the dam base are shown in fig.4. These fault and joints are modelled by the 3-D joint element.

The structural and mechanical characteristics of the 3-D joint element are shown in fig. 5 and fig. 6 . In the fig. 4 , the contact plane of the joint element- 1 is composed of foundation rock and foundation rock. The contact plane of the joint element-2 and -3 is composed of dam concrete and dam concrete. The contact plane of the joint element -4 is composed of foundation rock and dam concrete. The dynamic property values of these 4 kinds of joint elements can be set according to the structural material and the condition of contact plane.

The dynamic property values of the fault, the contraction joints, and the peripheral joint are assumed as shown in table $3 . \mathrm{Kn}$ is the dynamic shear modulus of joint plane in the normal direction. Ko is the dynamic shear modulus of joint plane in the tangential direction. $\mathrm{C}$ is the shear strength of joint plane. 


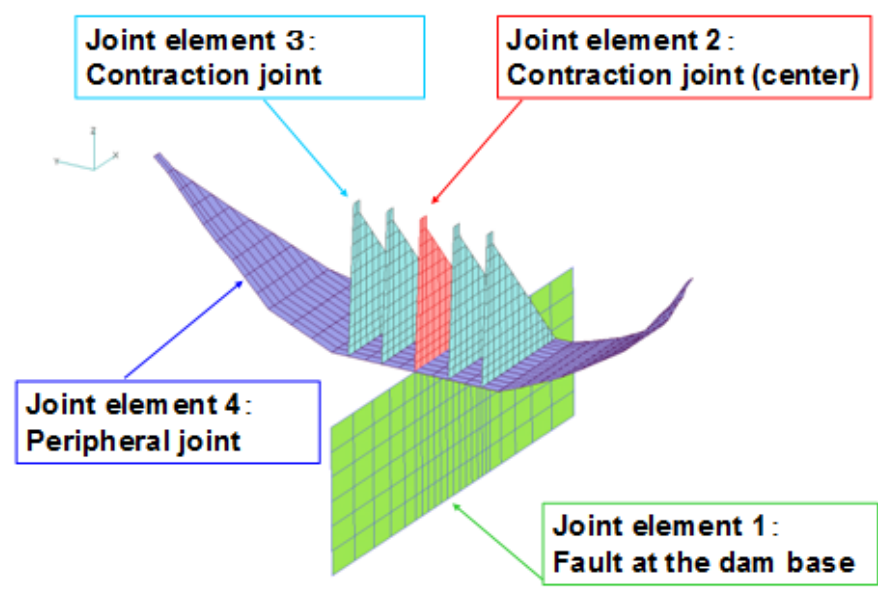

Figure 4: Distribution of the fault just below the dam, the contraction joints and the peripheral joint.

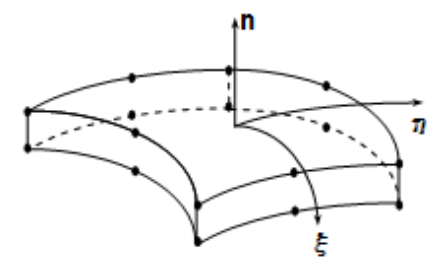

Figure 5: Structure of the 3-D joint element.

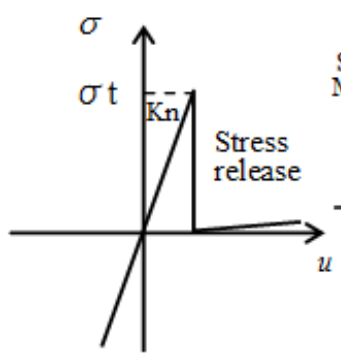

(1) Opening

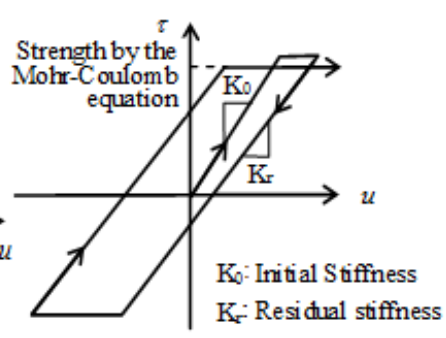

(2) Sliding

Figure 6: Mechanical characteristics of the 3-D joint element. 
Table 3: Dynamic property values of the fault, the contraction joints, and the peripheral joints.

\begin{tabular}{|c|c|c|c|c|c|c|c|c|c|c|}
\hline \multicolumn{2}{|c|}{$\begin{array}{c}\text { Kinds of } \\
\text { joints }\end{array}$} & $\begin{array}{c}\mathrm{Kn} \\
\mathrm{N} / \mathrm{mm}^{2}\end{array}$ & $\begin{array}{c}\mathrm{Ko} \\
\mathrm{N} / \mathrm{mm}^{2}\end{array}$ & $\begin{array}{l}\mathrm{C} \\
\mathrm{N} / \mathrm{m}^{2}\end{array}$ & $\begin{array}{c}\phi \\
\text { 度 }\end{array}$ & $\mathrm{Kr}$ & $\mathrm{C}^{\prime}$ & $\begin{array}{c}\phi^{\prime} \\
\text { K }^{2}\end{array}$ & $\begin{array}{c}\mathrm{Hj} \\
\%\end{array}$ & $\begin{array}{c}\sigma \mathrm{t} \\
\mathrm{N} / \mathrm{mm}^{2}\end{array}$ \\
\hline 1 & Fault & 243000 & 93000 & 0 & 45 & 1.0 & 0 & 45 & 5 & 0.01 \\
\hline 2 & $\begin{array}{l}\text { Dam } \\
\text { center }\end{array}$ & 264000 & 110000 & 0 & 45 & 1.0 & 0 & 45 & 5 & 0.01 \\
\hline 3 & $\begin{array}{l}\text { Dam } \\
\text { body }\end{array}$ & 264000 & 110000 & 0 & 45 & 1.0 & 0 & 45 & 5 & 0.01 \\
\hline 4 & $\begin{array}{l}\text { Dam } \\
\text { base }\end{array}$ & 243000 & 93000 & 4.5 & 45 & 1.0 & 0 & 45 & 5 & 3.00 \\
\hline
\end{tabular}

(Note : Kinds of joints correspond to Figure 4)

$\phi$ is the friction angle of joint. $\mathrm{Kr}$ is the dynamic shear modulus after opening or sliding. $C$ ' is the residual shear strength of joint plane after opening or sliding. $\phi '$ is the residual friction angle of joint plane after opening or sliding. $\mathrm{H}_{\mathbf{j}}$ is the damping factor of joint. And, $\sigma_{\mathbf{t}}$ is the initial tensile strength of joint. As for Kn and $\mathrm{Ko}$, the values 10 times as much as the ordinal values are assumed in order to suppress the deformation at the contact plane of joint elements.

\subsubsection{Boundary condition and input wave}

A free boundary is set at the right half of the bottom boundary in order to simulate a fault displacement, as shown in fig.7. An acceleration wave is input from the left half of the bottom boundary, which is rigid base. The right and left lateral boundaries are set to be a roller support in the vertical plane. The front and rear lateral boundaries are set to as a free boundary. By setting such boundary conditions, the right half of the 3-D model moves by the inertia force, and the discontinuous displacements occur along the fault. Consequently, the behaviour of dam against the fault displacement, the opening and sliding of the contraction joints and the peripheral joint, and the discontinuous displacement of dam can be analyzed. As for the input wave, the acceleration wave shown in fig. 8 is assumed, because it is thought that it is necessary to input very strong acceleration toward one direction in order to generate the discontinuous behaviour along the fault. The acceleration wave is expressed by the curve of second degree, which is convex down ward. The maximum amplitude of acceleration wave is $1 \mathrm{G}$, and the duration time is $3 \mathrm{sec}$.

\subsubsection{Results of the case study}

The analytical results about the displacement behaviours of dam and fault are shown in fig.9 and fig.11. Fig.9 shows the result when the acceleration wave is input in the horizontal up-down stream direction. In this case, the maximum relative displacement of joint elements at the centre of dam base was $0.18 \mathrm{~m}$. 


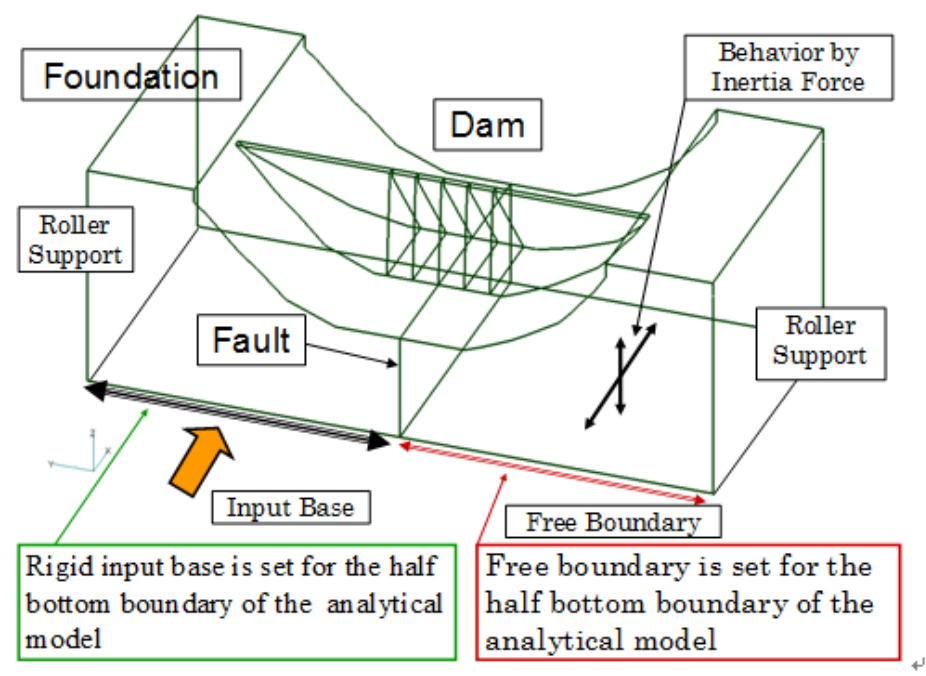

Figure 7: $\quad$ Boundary condition of the 3-D analysis model.

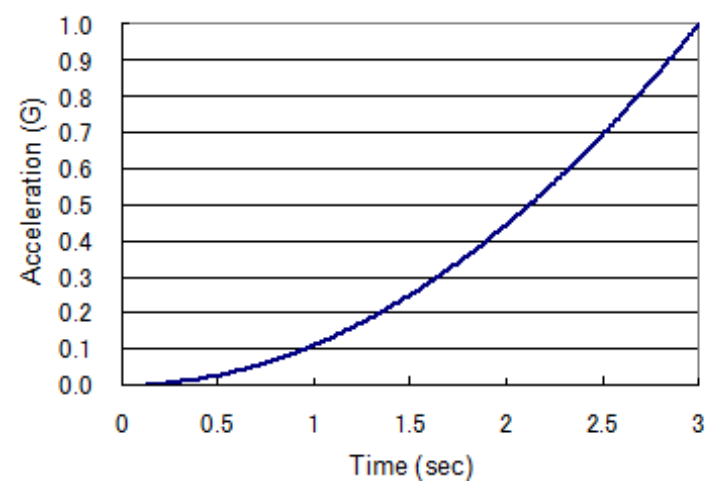

Figure 8: $\quad$ Acceleration wave assumed at the input base of the 3-D model.

Fig.11 shows the result when the acceleration wave is input in the vertical direction, and the maximum relative displacement of joint elements at the centre of dam base was $2.4 \mathrm{~m}$. In these cases, the vertical roller support is set at the right side of the joint elements.

Similarly, the analytical results about the time history of relative displacement of joint at the centre of dam base are shown in fig.10 and fig.12. Fig.10 shows the result when the acceleration wave is input in the horizontal up-down stream direction, and fig. 12 shows the result when the acceleration wave is input in the vertical direction. 


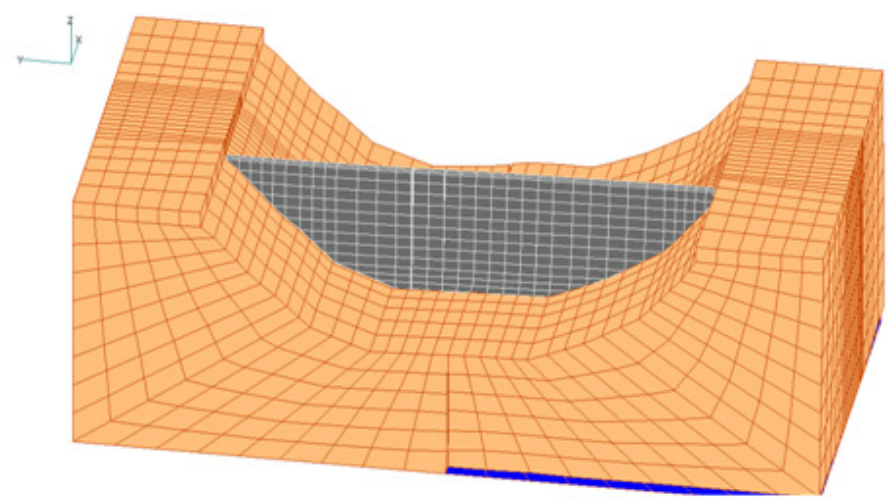

Figure 9: Discontinuous behaviour of dam induced by the fault displacement when the acceleration wave was input in the horizontal up-down stream direction.

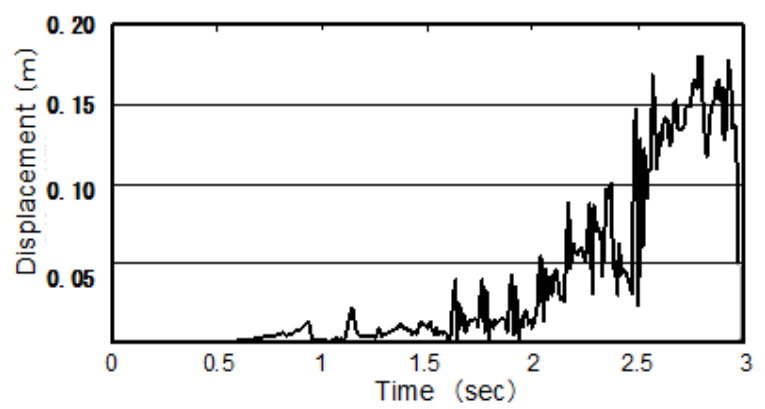

Figure 10: Time history of relative displacement of the joint at the centre of the dam base when the acceleration wave was input in the horizontal up-down stream direction.

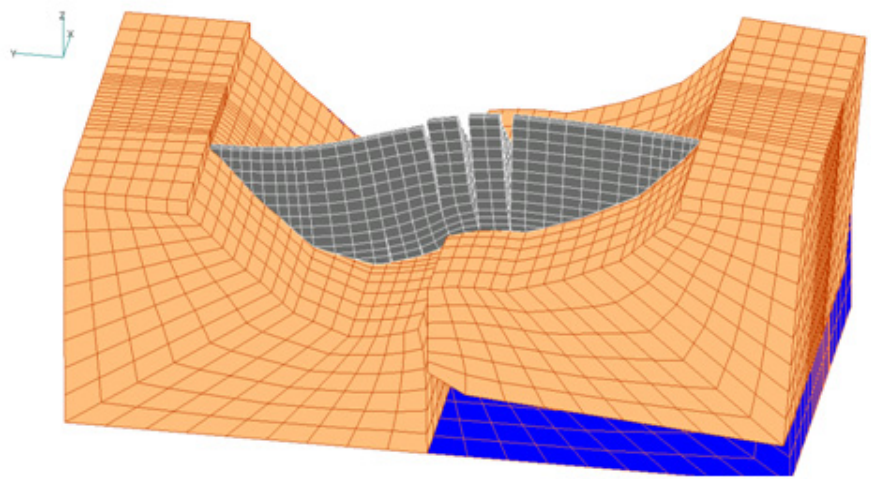

Figure 11: Discontinuous behaviour of dam induced by the fault displacement when the acceleration wave was input in the vertical direction. 


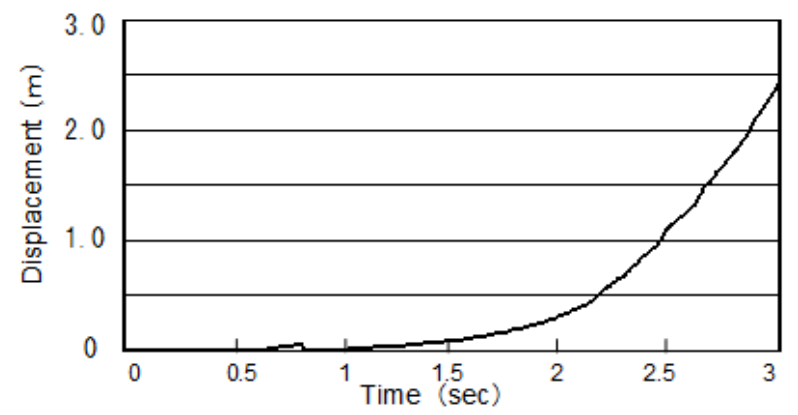

Figure 12: Time history of relative displacement of the joint at the centre of the dam base when the acceleration wave was input in the vertical direction.

Table 4: Maximum relative displacement at the centre of the dam base calculated by $3-\mathrm{D}$ analysis.

\begin{tabular}{|c|c|}
\hline Analytical case & $\begin{array}{c}\text { Maximum relative displacement } \\
\text { at the center of dam base }\end{array}$ \\
\hline 1 & $0.18 \mathrm{~m}$ \\
\hline 2 & $2.4 \mathrm{~m}$ \\
\hline
\end{tabular}

\section{Considerations}

Seismic safety evaluation against fault displacement induced by surface earthquake fault is an important subject for dam safety. In order to develop the evaluation method for dam safety against surface earthquake fault, we have devised a 3-D analysis method by applying 3-D dynamic analysis method for a coupled dam-joint-foundation-reservoir system.

Applicability of the method proposed was examined by the case study under the assumption that the fault is distributed just below the dam.

As the results, it is considered that the discontinuous behaviour and the residual relative displacement of dam-fault-foundation system can be simulated by the analytical method proposed in this study. A vertical fault displacement in connection with a normal fault or a reverse fault can be analyzed by inputting an acceleration wave in the vertical direction from the half of the rigid base of 3-D model. And, a horizontal fault displacement in connection with a strike-slip fault can be analyzed by inputting an acceleration wave in the up-down stream direction. By combining a horizontal input and a vertical input, it will be possible to simulate the various types of faults. 
A quantitative evaluation method for the dynamic property values of joints and fault, the value of damping factor corresponding to the boundary condition, the frequency and the amplitude of input wave, the analytical consideration on the vibration component of the time history of relative displacement of joints, and the verification of validity of the method proposed can be mentioned as the subjects for a future study.

\section{Postscript}

The analytical method proposed is effective for evaluating the discontinuous behaviours, and can be broadly applied for various kinds of structure-foundationfault system.

The prediction of earthquake occurrence and the estimation of earthquake motion have been the main issues in the conventional studies on the active fault thus far. For the future, the quantitative prediction of residual displacement along the surface earthquake fault will be the important theme.

\section{References}

[1] Sherard, J.L., Cluff, L.S. \& Allen, C.R., Potentially active faults in dam foundations, Geotechnique 24, No.3, pp. 367-428, 1974

[2] Leps, T.M., The influence of possible fault offsets on dam design, Water power \& dam construction, pp. 36-43, 1989

[3] Lee, J.C., Chu, H.T., Angelier, J., Chan, Y.C., Hu, J.C., Lu, C.Y. \& Rau, R.J., Geometry and structure of northern surface ruptures of the 1999 $\mathrm{Mw}=7.6$ Chi-Chi Taiwan earthquake: influence from inherited fold belt structures, Journal of Structural Geology 24, pp. 173-192, 2002

[4] Meguro, K. \& Ramancharla, P.K., Numerical study on the characteristics of the ground responses in the Near-Fault regions, Proceedings of $11^{\text {th }}$ Japan earthquake engineering symposium, Japanese Geotechnical Society, pp. 397-400, 2002

[5] Hori, M., Anders, M \& Gotoh, H., Model experiment and numerical simulation of surface earthquake fault induced by lateral strike slip, Structural Eng./Earthquake Eng., JSCE, Vol.19, No.2, pp. 227-236, 2002

[6] Konagai, K. and Johansson, J., Two dimensional Lagrangian Particle Finite Difference Method for modelling large soil deformation, Structural Eng./Earthquake Eng., JSCE, Vol.18, No.2, pp. 105-110, 2001

[7] Ariga, Y., Cao, Z., Watanabe, H., Seismic Stability Assessment of An Existing Arch Dam Considering the Effects of Joints, Proceedings of the $21^{\text {st }}$ International Congress on Large Dams, Q.83-R.33, pp. 553-576, 2003

[8] Ariga, Y., Tsunoda, S., Asaka, H., Determination of dynamic properties of existing concrete gravity dam based on actual earthquake motions, $12^{\text {th }}$ World conference on earthquake engineering, No.0334, pp. 1-8, 2000 